\title{
Euthanasia
}

\section{LATEST LEGAL AND SOCIAL DEVELOPMENTS IN THE EUTHANASIA DEBATE: BAD MORAL CONSCIENCES AND POLITICAL UNREST}

\section{N. Ferreira *}

\begin{abstract}
Several events that took place during recent years, such as the French Act on the rights of patients and the end of life, the Terri Schiavo case and Lord Joffe's proposal for an Assisted Dying Bill in the United Kingdom, have triggered the debate on euthanasia more than ever.

It is therefore opportune to revisit basic notions related thereto and to make a comparative analysis of the legal regime of euthanasia in several countries in Europe and elsewhere, as well as to try to see how the public awareness of the problem has of late developed.

There seems to be a clear trend in many legal systems towards an increasing respect for the patient's right to self-determination. However, we are still looking at a complex social game, where legal and medical terminology are manipulated and euphemisms are invented in order to accommodate bad moral consciences and avoid political unrest.
\end{abstract}

Keywords: Euthanasia; end-of-life; assisted suicide; active, passive and indirect euthanasia.

\section{INTRODUCTION}

The most modern life-sustaining and reanimation methods have come to prolong life beyond any previously anticipated time and state, leading to unexpected and negative consequences: the prolongation of suffering in cases of terminal illnesses, the maintenance of life under very diminished or inexistent conscience, and a whole range of conditions that cause life not to be worth living to the

\footnotetext{
* Lecturer in Law at the School of Law of the University of Manchester
} 
patients themselves. ${ }^{1}$ These medical conditions lead to the dissociation of the biological life (which persists) from the psychological life (which, to one extent or the other, does not exist anymore, such as in cases of irreversible coma or persistent vegetative state). ${ }^{2}$ This motivates many to argue for the legalisation of euthanasia.

Several events that took place during 2004, 2005 and 2006 have reanimated the debate on euthanasia more than ever. The French Senate approved a law regarding the rights of patients and the end of life ("Loi relative aux droits des malades et à la fin de vie"), which, according to many, was a big step towards legalising euthanasia. Two powerful and touching movies depicting the end of the lives of Spaniard Ramon Sampedro" ("Mar adentro") and American Maggie Fitzgerald ("One million dollar baby") were released and became big successes. Most importantly, the death of the American Terri Schiavo became a daily radio and TV serial drama in the houses of many families all over the world during March 2005. Finally, in November 2006, the British Royal College of Obstetricians and Gynaecologist called for a debate on the possibility of allowing

1. See C.A. Defanti, "Eutanasia, cambiamenti e norme", in Cosimo Marco Mazzoni (ed.), "Una norma giuridica per la bioetica", il Mulino, Bologna, 1998, pp. 237-250. It should, however, be made clear from the start that practices such as the so-called eugenic and economic euthanasia fall completely outside the scope of this article. The first one aims at selection in order to eliminate the weak and disabled from the society, thus 'improving' the human species. The second is the elimination of all people, sick or old, who are incapable of taking care of themselves, thereby removing the 'financial burden' to families and society. In any case, the correct understanding of euthanasia as it is discussed today has nothing to do with any of these. Political programs of race improvement or savage economic directives are in no way connected to allowing terminally ill patients in extreme pain to die in a dignified way.

2. Ibidem, p. 239.

3. Ramón Sampedro, a quadriplegic who spent the last 29 years of his life lying in bed, fought in court for five years for a 'dignified death', but his fight did not lead to any satisfactory conclusion. Notwithstanding the arguments invoked (the rights to dignity, free development of one's personality, life, physical and psychological integrity and a fair trial), no judge was convinced of his ultimate motto: "living is a right, not an obligation". In 2002 , he finally succeeded in his aim: he committed suicide with the assistance of eleven friends, one of whom was taken to court in 2005: the prosecution right fell, as the statute of limitations had run out, and the claim was archived: <http://www.20minutos.es/noticia/11693/0/ramona/maneiro/absuelta/>. 
euthanasia in the case of seriously disabled newborn children. ${ }^{4}$ It is, therefore, opportune to revisit basic notions related thereto and to pinpoint the most recent developments in this field in Europe and elsewhere, as well as to try to see how the public awareness and perception of the problem has of late developed. Furthermore, this paper assesses the relevance and workability of the distinction between passive, active, indirect, voluntary and non-voluntary euthanasia in several legal systems. The French debate on a possible "Loi Vincent Humbert", Lord Joffe's Assisted Dying Bill in the United Kingdom and the Spanish case of excessive sedation at the 'Severo Ochoa' hospital have stirred the arguments usually invoked by euthanasia advocates. It is extremely timely to assess these again. I adopt an interdisciplinary approach, embracing legal and sociological aspects, since it is more important to collect different perspectives that allow us to enrich the analysis, than to describe in detail legal technicalities that may cast shadows on the debate.

\section{The arguments and the distinctions}

Euthanasia can be classified in several ways. The most common distinction is that made between passive and active euthanasia. ${ }^{5}$ It amounts to the question of whether killing is actually worse than letting die. Even though Criminal Law provisions might determine equivalent sanctions, criminal offenders are, in practice, often more severely punished for an action than an omission. Similarly, passive euthanasia, which consists of ceasing or not starting life-saving treatment, usually gives rise to a milder punishment than active euthanasia, which can be defined as the specific intervention of a third person with the aim of ending someone's life. It remains, however, to be proved that there is actually a real difference between these two 'forms' of euthanasia, as we will see throughout this text.

4.Sarah-Kate Templeton, "Doctors: let us kill disabled babies", The Sunday Times, No. 9, 505 November 5, 2006; "Baby mercy 'killing' debate call", «ttp://news.bbc.co.uk/go/pr/fr/-/1/hi/ health/6120126.stm>.

5. See Council of Europe (COE), "Replies to the questionnaire for member states relating to euthanasia", http://www.coe.int/T/E/Legal Affairs/Legal co-operation/Bioethics/Activities/ Euthanasia/Answers\%20Euthanasia\%200uestionnaire \%20E\%2015Jan03.asp\#TopOfPage >. This document provides the definition of these concepts in each member state of the COE, all are very close to the ones provided by this paper. 
Another common distinction is the one between ordinary and extraordinary medical means. The first would be of currently utilised and proportionate efforts and the second would demand for extreme situations and disproportionate actions. Some authors accept more easily the suspension of extraordinary means of treatment rather than of ordinary means. However, it is obvious, especially to medical care professionals, that this is an excessively ambiguous distinction, mostly because all means to save life are, at least for most of the Western Europe and North American countries, ordinary for hospitals. This distinction is also extremely difficult to accept if we realise that what were unusual means in previous, recent years, are today common practice in any hospital, and that what is extraordinary in certain cases is ordinary for others and vice-versa. ${ }^{6}$

Finally, the concept of indirect euthanasia is also used in medical and legal texts. Indirect euthanasia means causing death through the prescription of drugs that, even if only aimed at making pain bearable, have the effect of knowingly accelerating the moment of death. It is what one can call an 'accepted secondary effect' of the fight against pain and has been accepted under the name of "doctrine of double effect". Providing large doses of painkillers, even when it leads to shortening the life of the patient, is expressly allowed in countries such as Albania, Denmark, Finland, Germany, Switzerland and the UK. ${ }^{7}$

The distinction which, however, actually possesses some value is that between voluntary and non-voluntary euthanasia. This is definitely the crucial distinction one has to draw, when making legislative decisions. It is according to this classification that we can make a clearer moral and ethical evaluation of the admissibility of euthanasia. ${ }^{8}$ Voluntary euthanasia refers to those cases where one person helps another in putting an end to his/her life, in response to a repeated and informed consent, under certain pre-established conditions, according to his/her request and/or will, and through painless means (one can include here the physician-assisted suicide and most cases of active and passive euthanasia). Traditionally, voluntary euthanasia finds justification upon three

6.. For more details, see M. Casado Gonzalez, "La eutanasia: Aspectos éticos y jurídicos", REUS, S.A., Madrid 1994, pp. 24-25.

7.. See COE, op. cit. See also, criticising the doctrine of double effect within the English context and in relation to specific case law, Suzanne Ost, "Euthanasia and the defence of necessity: Advocating a more appropriate legal response", Crim. L.R. 2005, May, 355-370.

8. For an exhaustive review of all arguments involved in this debate, see M. Otlowski, op. cit., pp. 187-256. 
main moral and (sometimes) judicial values: ${ }^{9}$

1) Prevention of cruelty: laws forbidding euthanasia are cruel, as they require a person to be kept alive against his/her will, while letting his/her physical and mental condition deteriorate;

2) Principle of autonomy and respect for self-determination: voluntary acts should always be permitted unless there are other secular legitimate interests which might require a different solution; ${ }^{10}$

3) Enhancement of human dignity: allowing the patient to control his/her own death is a way to ensure his/her dignity. ${ }^{11}$

On the other hand, the most relevant arguments opposing the legalisation of voluntary euthanasia are the following:

1) No ethical value of consent in the context of a 'right to die': the right to self-determination is outweighed by the value of life;

2) Difficulty in determining voluntary consent: when the patient is unconscious or is stupefied by drugs, and has not produced a living will;

3) Risk of incorrect medical diagnosis;

4) Possibility of new medical discoveries;

5) Use of modern drugs to control pain;

6) The slippery slope objection.

9. For an in-depth discussion of the arguments involving patient autonomy, advance directives, and, in general, ethical and moral arguments in favour and against the legalisation of voluntary euthanasia, see Suzanne Ost, "An analytical study of the legal, moral, and ethical aspects of the living phenomenon of euthanasia”, Symposium Series, Volume 76, The Edwin Mellen Press, Lewiston-Queenston-Lampeter, 2003, pp. 119-211.

10. For a thorough and interesting account of the most important considerations arising from the principle of autonomy and respect for self-determination, namely problems related to informed consent, medical care personnel's own autonomy and self-determination and the role and importance of living wills, see H. Biggs, "Euthanasia, death with dignity and the law", Hart Publishing, Oxford, 2001, pp. 95-144.

11. See, on the evolution of the concept of 'human dignity', the different possible concepts of 'human dignity', and its implications for bioethics, E. Montero, "Vers une légalisation de l'euthanasie volontaire? Réflexions à propos de la these de l'autonomie", Cahiers de la faculté de droit de Namur, 3, 1998; M. Otlowski, "Voluntary Euthanasia and the Common Law", Clarendon Press, Oxford 1997, pp. 205-206; H. Biggs, op. cit., pp. 145-174; A. Krajewska, "Fundamental Rights Concerning Biomedicine in the Constitutional Treaty and Their Effect on the Diverse Legal Systems of Member States", <http://www.germanlawjournal.com/article.php?id=666>. 
Considering all these arguments, one can legitimately argue that most objections to voluntary euthanasia fail on analysis and a properly drafted law can meet objections that have some greater force. In fact, the ethical value of consent is nowadays a deeply rooted concept in medical law, including cases of the refusal of life-saving treatment. ${ }^{12}$ This inevitably leads to the question of whether a request for euthanasia should not also be equally respected. The determination of voluntary consent in refusal of treatment cases where the patient is insensate is obtainable through growing awareness and promotion of living wills and the designation of health proxies. ${ }^{13}$ As for the risk of an incorrect medical diagnosis, a demand for a second physician's opinion practically eliminates such risk. Furthermore, the argument that there is a risk of there being a new medical discovery that could save the patient's life is null, as the relevant moment would not be the discovery of a new cure, but its availability for general use. When a patient can be considered for euthanasia, he/she has already reached the last stages of an incurable terminal disease and no new medical discovery would aid him/her. In addition, not even modern drugs relieve all patients from artificial and hopeless conditions or put an end to all the suffering felt by terminally ill patients. Finally, the slippery slope argument is not directed towards the merits of voluntary euthanasia itself, but rather predicts a catastrophic parade of supposed horrors that will follow the legalisation of euthanasia: the risks here discussed are rhetorical since carefully tested safeguards can be created. ${ }^{14}$

Cases of non-voluntary euthanasia, in contrast, concern persons who have not expressed their will to die, either because they have lost their mental or physical capacities, or because they have never had the capacity required. These cases relate mostly to palliative care. In such cases where non-voluntary euthanasia is advocated, palliative care has no therapeutic value; it only consists of artificially prolonging life when there is no possibility of a cure or improvement. Most medical teams and families already concur that medical care should no longer be pursued and favour ending the lives of patients in a chronic vegetative state,

12. See, for example, in the English context, $B \cup$ An NHS Trust [2002] 2 A11 ER 449.

13. The English Mental Capacity Act 2005, for example, allows for the appointment of a proxy decision maker (a donee of a power of attorney).

14. See S. Smith, "Evidence for the Practical Slippery Slope in the Debate on PhysicianAssisted Suicide and Euthanasia" Med Law Rev 2005 13: 17-44; S. Smith, "Fallacies of the Logical Slippery Slope in the Debate on Physician-Assisted Suicide and Euthanasia" MedLaw Rev 2005 13: 224-243. 
or those dependent upon life-supporting machines. ${ }^{15}$ Common practice does not justify in itself legalisation of non-voluntary euthanasia, but maintaining vegetative 'lives' in hospital beds endlessly is pointless for the patient, and causes families and medical teams to face a difficult and traumatic situation. Even though the family or medical team's interests should be absolutely secondary in a decision of such a personal character such as death, they still hold an auxiliary role under certain circumstances. Such considerations are in fact standard concerns in cases of patients in vegetative conditions, where both family members and medical staff have to ponder all aspects relevant to the case in question. ${ }^{16}$

\section{Recent developments in continental Europe}

The European Parliament (EP) has already contributed to the public debate on euthanasia. Some members of the EP have suggested that the European Union member states should move towards legalising euthanasia. ${ }^{17}$ However, in its formal declarations, the EP is considerably more cautious, stating the exact opposite. ${ }^{18}$ Furthermore, the generally accepted legal position with regards to

15. Particularly in regards to withdrawing treatment from permanently unconscious patients, see Suzanne Ost, "An analytical study of the legal, moral, and ethical aspects of the living phenomenon of euthanasia", op. cit., pp. 65-117.

16. It is relevant to refer, however, the recent case of a 53 year old woman in a permanent vegetative state at an English hospital. Despite the family's request to withdraw the feeding tube and letting the patient die, the Official Solicitor representing her did not agree. The High Court's family division refused the request of the family and allowed the administration of the drug Zolpediem, in an attempt to revive the patient. See 4 http://news.bbc.co.uk/1/hi/health/ 6164716.stm>.

17. "The European Parliament, (...) 28. Considers that the prohibition of torture and inhuman and degrading treatment, as well as the protection of human dignity, include the prohibition of over treatment, the promotion of palliative care, respect for the patient's wishes, as expressed through his or her will, for example; calls on the Member States to consider the possibility of amending laws on the end of life to this end by regulating euthanasia", Draft of EP Resolution, in Committee on Citizens' Freedoms and Rights, Justice and Home Affairs, Report on the situation as regards fundamental rights in the European Union (2003) (2003/2006(INI)). See <http://www2.europarl.eu.int/omk/sipade2?PUBREF=-//EP//TEXT+REPORT+A5-2004-

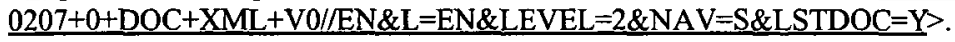

18. See, e.g., "Respect for human rights in the European Union in 1995", $<$ http://www2.europarl.eu.int/oeil/file.jsp?id=108582 $>$ and "Report on Fundamental rights situation in the European Union for 2001", http://www2.europarl.eu.int/oeil/ file.jsp?id=204772 >. 
euthanasia in most European countries is still quite repressive of practices related thereto. This is the case, for example, in Germany. The results produced by the existing provisions ${ }^{19}$ and case law are, in general, unsatisfactory and unfair. In fact, German courts have reached the incongruent point of, on the one hand, accepting the lawfulness of assisted suicide in case of patients capable of committing suicide by themselves, and, on the other hand, denying such assistance to those patients with disabilities which prevent them from ending their lives. ${ }^{20}$ More recently, a working group has been given the task of discussing the introduction of amendments to the law to better protect dying patients' autonomy. It was expressly out of the scope of this group's work to consider the legalisation of active euthanasia. ${ }^{21}$ The working group's discussion focuses upon how to protect patients' right to self-determination in practice. This reveals some progression in the German debate, which it is hoped, will eventually lead to more coherent, suitable rules and decisions.

It is also interesting to note that, even in countries where a repressive and traditional legal frame against euthanasia exists, case law can ensure some evolution. This is the case, for example, in Italy. In one particular case in this jurisdiction, Eluana Englaro had been in a vegetative state for 15 years. Although the Appeal Court of Milan denied the request of her father (and guardian) to withdraw the feeding tube and forced hydration, arguing that these are not therapeutic treatments, it also recognised that he had the right to express consent or refuse therapeutic treatment to his daughter. ${ }^{22}$

In France, the debate over euthanasia has recurred regularly during the last two decades. The Law of 4 March $2002^{23}$, regulating the rights of patients and

19. $\S \S 211-213$ and 323 of the Penal Code (Strafgesetzbuch, StGB).

20. For a better understanding of these case law, see K. Becker-Schwarze, "Möglichkeiten der rechtlichen Regulierung einer selbstbetimmten Entscheidung am Lebensende", in Gert Brüggemeier (Hrsg), "Liber Amicorum, Eike Schmidt zum 65. Geburtstag am 26.11.2004", C.F.Müller Verlag, Heidelberg 2005, pp. 1-31.

21. "Bericht der Arbeitsgruppe ,Patientenautonomie am Lebensende' vom 10. Juni 2004", $<$ http://www.bmi.bund.de $>$. For more details on the present debates, see K. Becker-Schwarze, op. cit., p. 2.

22. Reported in "La Reppublica", 22 March 2005, p. 16. The appeal to the Supreme Court (Cassazione) was also refused: <http://www.repubblica.it/2005/c/sezioni/cronaca/eutanasia/ deciscassaz/deciscassaz.html>.

23. "Loi relative aux droits des malades et à la qualité du système de santé", Loi n ${ }^{\circ} 2002-303,4$ March 2002, JO n 54, on 5 March 2002, pp. 4118 ff., <http://www.legifrance.gouv.fr $>$. 
the quality of the health care system, empowered the protection of the right to dignity of the sick person and moved towards greater respect for the patient's freedom and right to refuse treatment. ${ }^{24}$ In 2004, a law proposal on "the rights of patients and to the end-of-life" found enough supporters in the Senate. ${ }^{25}$ The report prepared by a special commission of the French Assemblée Nationale ${ }^{26}$ on this proposal found that the legislator should improve and modernise the status quo, without completely legalising euthanasia. It was stated that this proposal would take into account the common practice in hospitals, which included, for example, the actual turning off of between 75.000 and 100.000 life support machines, and the patients' desire for more legal certainty. This legal proposal was eventually approved and recognises the right to refuse life-sustaining treatment, that is, to passive euthanasia, even in the case of patients who are not at the end of life (Articles 1 and 6). It also establishes that the decision regarding the cessation of treatment of an unconscious patient has to be taken through a collegial procedure; thus significantly, passive euthanasia is also permissible for unconscious patients (Articles 5 and 9). Furthermore, indirect euthanasia is also accepted, provided the patient is aware that this is taking place (Article 2). Finally, the legal value of living wills is recognised (Article 7). As the rapporteur of the report on this law, M. Jean Leonetti, argued, this law places the right to freedom and human life autonomy, as well as respect for the person, at the centre of the debate. However, the "Loi Leonetti" is still considered by many as a very restrictive legal solution, given that assisted suicide still remains completely prohibited. A particular movement for the liberalisation of euthanasia in France calls for a "Loi Vincent Humbert". ${ }^{27}$ Vincent Humbert, a paraplegic, died in September 2003 after he repeatedly requested that his mother and a physician help him to die. ${ }^{28}$ The mother and the physician faced sentences of 5 and 20 years imprisonment respectively, but the court decided not to proceed with the case

24. Answer to question $\mathrm{I} .2$ of COE, op. cit.

25. "Loi relative aux droits des malades et à la fin de vie", Loi n 2005-370, 22 April 2005, JO n 95, 23 April 2005, <http://www.senat.fr/dossierleg/ppl04-090.html >.

26. "Rapport fait au nom de la Commission Spéciale chargée d'examiner la proposition de loi ( $\mathrm{n}^{\circ}$ 1882) de $M$. Jean Leonetti et plusieurs de ses collègues relative aux droits des malades et à la fin de vie", $<$ http://www.assemblee-nationale.fr/12/rapports/r1929.asp $>$.

27. <http:// www.loi-vincent-humbert.com>.

28. $<$ http: $/ /$ www.liberation.fr/page.php?Article $=257255 \& A G>$. 
and it was withdrawn. ${ }^{29}$ The actions of the mother and physician in this case, which were greeted with great sympathy by the media, were not permissible under the Loi Léonetti. Therefore, many who support the legalisation of euthanasia disapprove of the Loi Léonetti and call for a more progressive law. ${ }^{30}$

Spain offered us the striking and poignant Sampedro case, which inspired the afore-mentioned film "Mar adentro" and provided grounds for international case law. Ramón Sampedro's heir, Manuela Sanlés Sanlés, proceeded with his legal claims and eventually appealed to the European Court of Human Rights (ECtHR). She argued that Spain had violated the right to a life of dignity and a dignified death in respect of Sampedro, the right to non-interference by the state in the exercise of his freedom, and his right to equal treatment. The claim was considered inadmissible ratione personae, since an heir was not entitled to pursue such proceedings. The case then reached the Human Rights Committee of the United Nations. ${ }^{31}$ The heir claimed a violation of Sampedro's rights not to be subjected to inhuman or degrading treatment, to life, to freedom of thought and conscience and to manifest his personal beliefs through practices or deeds, to liberty and to equal protection of the law (Articles 7, 6, 18, 9, 2, 26 International Covenant on Civil and Political Rights). The case was considered inadmissible by reason of Sampedro having committed suicide and the authorities not having pursued proceedings against those involved. Also in Spain, in 2005, a medical scandal raised awareness about 'indirect' euthanasia. Anonymous communications alerted the sanitary inspection authorities to about 400 cases of excessive sedation in a particular hospital in the region of Madrid. ${ }^{32}$ All physicians who were members of the internal commissions of the hospital

29. $<$ http://www.lefigaro.ff/debats/20060320.FIG000000272 le choix de vincent mon combat. html?100559>.

30. For further details and discussion on the legal situation in regards to all forms of assisted dying in France, in particular the role of the French national bioethics advisory commission (Comité Consultatif National d'Ethique - CCNE), see Penney Lewis, "Assisted dying in France - The evolution of assisted dying in France: A third way", Medical Law Review, 14, Spring 2006, pp. 44-72.

31. Communication no. 1024/2001, Sanles Sanles v. Spain, (Decision adopted on 30 March 2004, eightieth session), in Report of the Human Rights Committee (Volume II), pp. 505-511: $<$ http://www.unhchr.ch/tbs/doc.nsf/0/f0c6766939e65645c1256ffd0024998f/SFILE/ G0443700.pdf $>$.

32. $<$ http://www.20minutos.es/noticia/15299/0/lamela/leganes/hospital/s. 
resigned as a sign of protest against the suspicions raised. ${ }^{33}$ However, the experts called upon to investigate the allegations did conclude that there were 73 cases of "inadequate or not recommended" sedations ${ }^{34}$ and 4 physicians involved in these cases faced disciplinary proceedings as a consequence. ${ }^{35}$ The matter also reached the courts and, after serious doubts regarding the impartiality and independence of the above mentioned experts were expressed by several entities ${ }^{36}$, the Madrid Medical Association was asked by the court to produce a report on the case. The conclusions reached by this commission in May 2006 were in line with the previous findings ${ }^{37}$ : from the 73 cases of sedation under investigation, in 4, sedation was countermanded, in 10 it was not recommended, and in 20 it was not necessary. The majority of the patients suffered from very serious pathologies and were expected to die within a very short period of time. Although sedation was considered unjustified in 34 cases, this report was unable to establish with certainty a link between excessive sedation and the deaths. A judicial decision, based on this report is yet to be made by the court. Whatever happens, Prime Minister Zapatero has already declared that the executive has no intention of amending the rules prohibiting euthanasia, although this case and the reactions thereto indicate that indirect euthanasia is commonly accepted by health care providers in Spain. ${ }^{38}$

The situation in Switzerland is radically different. In recent years, Switzerland has been accused of facilitating what harsh critics describe as 'death tourism': terminally-ill patients travel to the country in order to be allowed to die through medical assistance that is denied in their own countries. ${ }^{39}$ In fact, assisted suicide is legal (as long as the assistor is not driven by a selfish motive) ${ }^{40}$ and the medical-ethic directives of the Swiss Medical Sciences Academy allow

33. $<$ http://www.20minutos.es/noticia/19055/0/severo/ochoa/leganes $>$.

34. $<$ http://www.20minutos.es/noticia/26838/0/sedaciones/severo/ochoa/ $>$.

$35<$ http://www.20minutos.es/noticia/28089/0/Expediente/suspenso/medicos $>$.

36. <http://www.elmundo.es/elmundo/2005/05/26/madrid/1117106245.html > .

37. $<$ http://www.icomem.es $>$.

38. <http://www.20minutos.es/noticia/17268/0/eutanasia/zapatero/legalizacion/>.

39. $\angle$ http://news.bbc.co.uk/1/hi/uk politics/2782887.stm $>$ and $\measuredangle$ http://news.bbc.co.uk/1/hi/ health $/ 3623874 . \mathrm{stm}>$. The same is said to happen in the Netherlands, but in smaller proportions: Abigail Levene/Reuters, Público, 1 April 2002, p. 19.

40. Article 115 Penal Code, e contrario; see answer to question II.9 of COE, op. cit. 
both passive and indirect active euthanasia ${ }^{41}$ Furthermore, between $75 \%$ and $80 \%$ of the population actually supports active euthanasia. ${ }^{42}$ In October 2005 , the Federal council approved a party motion that proposes to legislate on the practice of passive and indirect euthanasia. ${ }^{43}$

The ultimate paradigm of euthanasia in practice in today's world occurs in The Netherlands. ${ }^{44}$ With the approval of the Termination of Life on Request and Assisted Suicide (Review Procedures) Act, The Netherlands became the first country in the world to legalise active euthanasia provided that certain statutory criteria are met. ${ }^{45}$ In 2000, the Dutch government has made it clear that this Act does not, in any way, need to be amended as a consequence of the ECtHR's decision in the Pretty case.$^{46}$ In fact, the Dutch law is compatible with Article 2 of the European Convention of Human Rights (ECHR), since it does not allow for a 'right to euthanasia' and doctors cannot be obliged to accede to

41. The ASSM Directives on medical assistance to patients at the end of life or to patients suffering from extreme brain problems do not have legal status, but the political authorities recognise their validity and courts refer to their dispositions. Since these directives allow both passive euthanasia and indirect active euthanasia, authorities consider these practices lawful (see the Swiss answer to question II.5 of COE, op. cit.).

42. See Service des Affaires Européennes du Sénat, " $L$ 'euthanasie - Étude de législation comparée n' 49", January 1999 , <http://www. senat.fr/lc/lc49/lc49 mono.html $>$.

43. <http://www.parlament.ch/afs/data/f/gesch/2005/f_gesch_20053352.htmp.

44. The Medical Association of Netherlands is the only one in the world to accept that medical practices include helping patients achieve a peaceful and dignified death. For an analysis of the Dutch legal regime, see U. de Vries, "A Dutch perspective: the limits of lawful euthanasia", 13 Annals Health L. 365,2004 . The practice of euthanasia was also legalised in Belgium a few years after the Dutch statute came into being: Act of 28 May 2002 on euthanasia.

45. "Wet van 12 April 2001 houdende toetsing van levensbeëindiging op verzoek van hulp bij zelfdoding en wijziging van het wetboek van strafrecht en van de wet op lijkbezorging", Staatsblad 2002, 165. Doctors now have specific defence under Part 2 of Article 293 of the Dutch Penal Code provided that they follow the Due Care' criteria laid out under section 2 of the Termination of Life on Request and Assisted Suicide (Review Procedures) Act and act in accordance with the provisions of section 7, subsection 2 of the Burial and Cremation Act.

46. Pretty v. the United Kingdom 2 F.L.R. 45. The ECtHR decision stated that, although the English legal solution was justifiable, "that is not to say that no other law or application would be consistent with the Convention, it is simply that the present legislative and practical regimes do not offend the Convention": $§ 30 \mathrm{Ibidem}$. 
requests for euthanasia. ${ }^{47}$ Moreover, the Dutch legal regime strikes a balance between protecting the right to life and the right to personal autonomy, the importance of which the ECtHR underlined. In 2004, the Dutch Authorities promoted a new independent study to assess how this Actwas working in practice. ${ }^{48}$ This report concludes that the main focus should be on increasing compliance with the due care criteria, which has been found to have increased anyway since 1995 . The report also found that the growing transparency clearly shows the positive effects of adopting legislation regulating medical practices that already occur (such as euthanasia, be it passive, indirect or active), rather than forbidding them and then ignoring their illegal practice. Concerns still exist about abuses in the Dutch practice of euthanasia regarding non-reporting of cases and the consequential impossibility to verify whether the criteria have been satisfied, as well as high level of non-compliance with all the legal criteria in the cases reported. ${ }^{49}$ But even if the Dutch experience shows the difficulty of holding the line against slippage across the crucial established criteria, it is also clear that the predicted nightmare slippery slope scenarios have not materialised. The harsh analysis of the Dutch legal solution provided by some authors ${ }^{50}$ can hardly be upheld: there is no thorough, comparable data on the same parameters as the Dutch surveys in other countries, which should forestall any comprehensive conclusion on, let alone condemnation of, the Dutch euthanasia policy.

47. The Supreme Court (Hoge Raad) decided in the Brongersma case, December 2002, that the mere repeated request for termination of life does not suffice (HR, no. 00797/02, 24 December 2002, NJ (Dutch Law Reports) 2003, 167). The patient in this case was not terminally ill, but simply "tired of living". These circumstances did not allow for the removal of physician's culpability, since the objective criteria established by Dutch law was not respected. Therefore, the right to personal autonomy sometimes has to cede to the protection of the right to life, and euthanasia is still criminally punishable under certain circumstances.

48. See Comments by the Government of the Netherlands on the concluding observations of the Human Rights Committee (CCPR/CO/72/NET), International Covenant on the Civil and Political Rights, Human Rights Committee of the United Nations, CCPR/CO/72/NET/Add.3, 16 December 2004.

\section{Ibidem.}

50. See, e.g., J. Keown, "Euthanasia, ethics and public policy: an argument against legalisation", Cambridge University Press, Cambridge et. al. 2002, pp. 136-149. 


\section{Evolution in Common Law countries}

In England, after Diane Pretty's well publicised case travelled a long judicial journey through the High Court, the House of Lords and the ECtHR, in 2002, another case reached the media and became a milestone in the evolution of the legal position upon euthanasia in England. The High Court ruled that the ventilator keeping Miss $B$ alive could be switched off. ${ }^{51}$ Miss $\mathrm{B}$ was completely conscious, provided a repeated request and gave full, informed consent. As Miss B's defence lawyer stressed, the legal distinction between his client and Mrs Pretty was a "technicality", which "does not have any bearing on the real world". 52 Miss B was the first British citizen to request the withdrawal of life-sustaining treatment while still conscious. All previous cases that had reached English courts up to this point involved solely patients in a persistent vegetative condition. In regards to medical treatment in such situations, it is relevant to mention the approval of the Mental Capacity Act in 2005, which has provided statutory recognition for advance directives. ${ }^{53}$

In 2004, Lord Joffe presented his Assisted Dying Bill before the House of Lords. ${ }^{54}$ This bill provided for a competent adult suffering from a terminal disease or a serious, incurable physical illness to request medical assistance to die. Despite support from over $80 \%$ of the population for such a bill ${ }^{55}$, in May 2006, the Lords decided to postpone the reading of the Bill for a period of six months. ${ }^{56}$ This move has avoided parliamentary debate on the Bill, just as happened in 10 December 1997 to the bill MP Joe Ashton proposed.

More recently, the idea of taking greater account of the alternatives of nonresuscitation, withdrawal of treatment and active euthanasia in cases of sick newborns found support from different academic and practice sources. ${ }^{57}$

51. B v An NHS Trust [2002] 2 Al1 ER 449.

52. $<$ http: $/ /$ news.bbc.co.uk $/ 1 / \mathrm{hi} /$ health $/ 1890624 . \mathrm{stm}>$.

53. $<$ http://www.opsi.gov.uk/acts/acts2005/20050009.htmp.

54. <http://www.publications.parliament.uk/pa/ld200304/1dbills/017/2004017.htm>.

55. <http://news.bbc.co.uk/1/hi/uk politics/2782887.stm $>$.

56. <http://news.bbc.co.uk/2/hi/health/4763067.stmp and

$<$ http://www.publications.parliament.uk/pa/ld199900/ldhansrd/pdvn/lds06/text/6051201.htm\#topichd 2>.

57. Sarah-Kate Templeton, op. cit. 
However, the possibility of active euthanasia in these cases, in particular, has been criticised by some as 'social engineering' or a border which should not be crossed. This was also the conclusion reached by the Nuffield Council on Bioethics Report on "Critical care decisions in fetal and neonatal medicine: ethical issues", which "unreservedly rejects the active ending of neonatal life even when that life is 'intolerable". ${ }^{58}$ More detailed guidelines are, however, given in this report in regard to babies born prematurely, depending on the exact number of weeks of gestation. The report reaches, for example, the conclusion that babies born before the completion of 22 weeks of gestation should not be resuscitated at all. ${ }^{59}$ In any case, more debate over these issues is expected in the near future in the UK. Approaches that involve "stringent cut-off points for treatment" have already been considered inadequate by Tony Calland, the Chairman of the Medical Ethics Committee of the British Medical Association, who declared that "[e]ach case should be considered on its merits and its own context". ${ }^{60}$

On the other side of the globe, in 2003, the Death with Dignity Bill was rejected by the New Zealand parliament, by 60 votes to $57 .{ }^{61} \mathrm{~A}$ more recent event again raised the issue of euthanasia in this country. Andrew Morris, a man who suffered from progressive bulbar palsy, a motor neuronal disease, died on 9 March 2005, after having vowed to starve himself to death. Andrew Morris "planned to stop eating while he could still feed himself', since he did not wish anyone to be criminally punished for helping him to die. ${ }^{62} \mathrm{He}$ eventually died of pneumonia, in connection to his refusal to have a gastro/feeding tube inserted that would artificially sustain him. The person who voluntarily took care of him, Phillipa Grace, respected the patient's wishes and only gave him water until he died. Although she was not prosecuted for Mr. Morris' death, the police did mention that a prosecution "could" be brought. ${ }^{63}$ This case again reveals the extremely thin line between what action should be punishable or not. While it

58. See pp. $19-20$,

$<$ http://www.nuffieldbioethics.org/fileLibrarv/pdf/CCD web version 8 November.pdf $>$.

59. Ibidem, pp. 155-156.

$60 .<$ https://registration.bma.org.uk/pressrel.nsf/wlu/STRE6VKCU2?OpenDocument \&vw=wfmms $>$.

61. $\langle$ http://www.nzherald.co.nz/index.cfm?c id=1\&ObjectID=10007151 $>$.

62. Ibidem.

63. <http://www.20minutos.es/noticia/10304/0/eutanasia/ramon/sampedro/>. 
may be true that Phillipa Grace had the duty to assist and could be legally charged with homicide through omission to rescue, it is also obvious that Andrew Morris merely exercised his right to self-determination. This vivid example of patient autonomy illustrates how the traditional criminal law rules have to be re-examined and reformed.

Following this line of thought, the patient's right to self-determination is ranked highly in the USA. ${ }^{64}$ Further, all American states have adopted laws recognising each person's right to express in advance his/her refusal of medical treatment, either by producing a living will or by designating a proxy with decision-making power regarding medical issues. ${ }^{65}$ This said, the situation regarding all euthanasia related issues in several states of the USA is extremely controversial. Thousands of deaths everyday are alleged to be in some way planned, tolerated or indirectly assisted, probably through the double effect of pain-relieving medications that hasten death, or the withdrawal of or failure to start potentially life-prolonging or life-saving treatments. ${ }^{66}$ The Oregon Death with Dignity Act made physicianassisted suicide lawful for the first time in the world, provided the doctor conforms to certain specifications ${ }^{67}$ Although the number of people resorting to physician-assisted suicide has been increasing since 1998, the overall number of deaths occurring through this means only amounts to about $0,125 \%$ of the annual deaths. ${ }^{68}$ Another important issue is that no unreported cases have been identified, not only according to the authorities, but also to several authors, which may well suggest that the Act is well enforced. ${ }^{69}$ More importantly, the

64. See Patient Self Determination Act 1990, <http://thomas.loc.gov/>. As far back as 1914, in the case of Schloendorff $v$ Society of NY Hospital, 211 NY 125, 105 NE 1914;92:93, Judge Cardozo stated that: "every human being of adult years and sound mind has a right to determine what shall be done with his own body".

65. Service des Affaires Européennes du Sénat, op. cit..

66. The New York State task force on life and the law, "When Death is Sought. Assisted Suicide and Euthanasia in the Medical Context", <http://www.health.state.ny.us/nysdoh/consumer/patient/preface.htmp.

67. In 1994, the voters of Oregon approved, in referendum, the law legalising assisted suicide, "The Oregon Death with Dignity Act", <http://oregon.gov/DHS/ph/pas/docs/statute.pdf>

68. Department of Human Services, Office of Disease Prevention and Epidemiology, "Seventh Annual Report on Oregon's Death with Dignity Act", 10 March 2005: <http://egov.oregon.gov/DHS/ph/pas/docs/year7.pdfs.

69. Ibidem; Tolle, Tilden, Drach, et al, "Characteristics and proportion of dying Oregonians who personally consider physician assisted suicide", J Clin Ethics, 2004; 15, pp. 111-118. 
Oregon Health Division could not find any sign of abuse, or of patients being influenced to request assistance to die because of the financial burden of their disease. Finally, the availability of physician-assisted suicide has had the positive impact of increasing physicians' awareness in regards to end-of-life care options, such as pain medication in the terminally ill, recognition of disorders such as depression and referral of patients to hospices.

The most recent and lively debate upon euthanasia in the USA concerns the Terri Schiavo case. Terry Schiavo, aged 41, died on 31 March 2005, after 15 years of being in a vegetative state and 13 days of starvation and dehydration. This dramatic case revolved around the issue of who should decide about someone's right to die when that person is no longer competent and has not left any living will? After what seemed to be a never-ending entanglement of court processes, appeals and procedural issues, the state circuit court ordered the removal of the life-sustaining feeding tube and the Supreme Court rejected the appeal against this decision, based on Schiavo's persistent vegetative state and alleged wishes. ${ }^{70}$ What was most disturbing and specific to this case was the media and political attention that it caught. The seven year judicial marathon involved 20 rulings and 5 refusals of the Supreme Court to hear the case. ${ }^{71}$ One significant issue is that the majority of Americans condemned the hasty intervention of Congress in the judicial process ${ }^{72}$ and were in favour of the removal of the feeding tube, independently of their individual political or religious backgrounds. ${ }^{73}$ Finally, this case also had the consequence of making people more willing to safeguard respect for their right to self-determination during sickness: during the days of highest controversy around the case of Terri Schiavo, more than 2000 people a day asked the organisation "Aging with Dignity", specialists in drafting living-wills, for advice. ${ }^{74}$

70. <http://edition.cnn.com/2005/LAW/03/30/schiavo/index.html $>$ $<$ http://edition.cnn.com/2005/US/03/31/schiavo/index.html $>$.

71. <http://edition.cnn.com/2005/LAW/03/24/schiavo/index.html>.

72. According to a poll conducted by ABC TV station, $70 \%$ of the Americans believe that the president and the Congress should not have interfered in this case, reported the "Corriere della Sera", 22 March 2005, p. 9, and "La Reppublica", 22 March 2005, p. 8.

73. Ibidem. See also <http://edition.cnn.com/2005/LAW/03/23/schiavo.poll/index.html>.

74. Reported by "La Reppublica", 22 March 2005, p. 8. See also <http:// www.agingwithdignity.org/>. 


\section{Some considerations and comparative remarks}

The different legal solutions to the ethical conundrum of euthanasia adopted in the countries considered reveal the deep and irreconcilable differences that characterise the dilemma posed by euthanasia across the world. Even countries that have legalised euthanasia, such as the Netherlands and Belgium, have followed different paths. While in the Netherlands, the criminal law provisions under the Penal Code regarding the taking of life following the patient's request and assisted suicide were amended, in Belgium the penal code has not been amended and there is no explicit reference to assisted suicide. Furthermore, in Belgium, the request for euthanasia has to be a written request, whereas in the Netherlands it does not. ${ }^{75}$

A seemingly obvious conclusion is that there seems to be a clear trend towards the legal recognition of living wills in recent years. Among the legal systems that have followed this trend, we can count England, Denmark, several Swiss cantons, half of the Australian States or territories and all American States. All of these jurisdictions have adopted laws recognising each person's right to express in advance his/her refusal of medical treatment, either by producing a living will or by designating a proxy with decision-making power regarding medical issues. ${ }^{76}$

Another significant matter also stands out: the distinction between indirect, passive and active euthanasia has very limited value: it lacks clarity and is mostly irrelevant. Denmark offers a particularly striking example of how the borderline between these supposedly different concepts is blurred to the point of making them almost impossible to apply. Whilst, on the one hand, 'active' euthanasia is still forbidden in Denmark, on the other hand, both 'passive' and 'indirect' euthanasia have been officially recognised and regulated in this jurisdiction by the Medical Profession Exercise Act 1992 and the Patient Status Act 1998. However, a report of the Ethics Committee from $1996^{77}$ showed that 1 in 10 physicians resorted too readily to the prescription of morphine to shorten the lives of dying patients. A practice consensually considered to be in

75. Service des Affaires Européennes du Sénat, "L'euthanasie - Étude de législation comparée $n^{\circ}$ 109", July 2002, <http://www.senat.fr/lc/lc109/lc109.pdf>, pp. 4-5.

76. Service des Affaires Européennes du Sénat, "L'euthanasie - Étude de législation comparée $n^{\circ}$ 49", op. cit.

77. Ibidem. 
accordance with medical ethics is only one step away from active euthanasia, which should surely lead us to doubt the correctness of the traditional categories of 'active', 'passive' and 'indirect' euthanasia. ${ }^{78}$

Where does 'passive' euthanasia end and 'active' euthanasia begin? What reason is there to think that it is less ethically acceptable to leave a baby in extreme pain for several days in a row until he/she dies than terminate his/her life with a lethal injection and thereby end suffering? Not doing anything is already doing something; it is deciding what to do, just as it is to act. ${ }^{79}$ As Defanti, a physician himself, argues, the decision to not resort to life sustaining means or to suspend such means once commenced cannot be considered a mere case of omission, for one has already made a decision. ${ }^{80}$ Moreover, both 'indirect' and 'active' euthanasia behaviours can share the same characteristics: ${ }^{81}$

1) intention: to bring relief to the patient's pain and provide him/her with a painless death;

2) motivation: to assist the patient to the best of the physician's ability;

3) act: the administration of a certain drug;

4) result: the death of the patient.

In fact, to intend an outcome is not only to aim for a specific result: the legal notion of intention also encompasses knowing that a certain result will undoubtedly take place following that action. ${ }^{82}$ And it cannot be said, alluding to the German theory of the "consented risk", that indirect euthanasia remains

78. See, again, in regards to the inadequacy of the doctrine of double effect, Suzanne Ost, "Euthanasia and the defence of necessity: Advocating a more appropriate legal response", $o p$. cit.

79. See, for a critical analysis of arguments from authors such as Nesbitt, Ognall, Rachels, Singer, and Kuhse, as well as further discussion on the moral distinction between ending life through the withdrawal of treatment and ending life through the administration of lethal treatment, Suzanne Ost, "An analytical study of the legal, moral, and ethical aspects of the living phenomenon of euthanasia", op. cit., pp. 49-64.

80 See C.A. Defanti, op. cit., p. 245.

81. I. Kennedy, "Il diritto di morire", in Cosimo Marco Mazzoni (ed.), op. cit., pp. 217-236.

82. See, also, Suzanne Ost, "Euthanasia and the defence of necessity: Advocating a more appropriate legal response", op. cit. 
non-intentional killing, as long as the administration of drugs remains within certain limits, otherwise one has, then, to answer what that limit might be. And there is, obviously, no limit, since the pain of the patient may not have any such confines and require painkillers to be controlled to any degree until he/she is dead. ${ }^{83}$

Therefore, 'indirect' and 'active' cases of euthanasia are considerably more similar than it may initially seem. In addition, the presumed distinction between assisted suicide and 'active' voluntary euthanasia is, in Kennedy's words, illusory: it easily crumbles both from the factual and from the moral points of view. ${ }^{84}$ Consequently, the existence of different normative and judicial solutions for all these cases lacks sufficient legal ground. It is more a question of rhetoric: neither the means (the administration of a drug), nor the result (the death of the patient) is considered wrong, but the rhetoric and ritual around them make all the difference. ${ }^{85}$ Thus, criminal systems that enforce this rhetoric and ritual are arguably misguided.. Furthermore, the fact that such systems aim to protect patients is patently ironic, since in the context of euthanasia, the patients in question actually wish to avoid being protected. The active intervention, such as administering a lethal drug that interrupts both (unbearable) pain and life immediately, is more beneficial for the patient than passively waiting for a death which in many cases causes the patient to experience long, pointless agony. ${ }^{86}$ The existence of different normative and judicial solutions for different categories of euthanasia lacks sufficient ground. Omissions and actions should, as far as the euthanasia debate is concerned, deserve the same legal treatment.

\section{CONCLUSION}

Maintaining the rules that prohibit practices related to euthanasia and occasionally applying them in a more flexible way, taking into consideration the specific circumstances of a case, "inevitably produces uncertainty and does

83. F. Giunta, "Diritto di morire e diritto penale", in Cosimo Marco Mazzoni (ed.), op. cit., p. 259.

84. I. Kennedy, op. cit.

85. In the same sense, see P. Rescigno, "Autodeterminazione e testamento in vita", in Cosimo Marco Mazzoni (ed.), op. cit., pp. 283.

86. C.A. Defanti, op. cit., pp. 246; L. Schwarzenberg, "Penser l'euthanasie", in Pinsart M.-G. et Susanne C. (éds.), op. cit., pp. 89-97, especially p. 96. 
not adequately protect the position of either doctors or their patients". ${ }^{87}$ Tolerating "the discrepancies which presently exist between the law on the books and the law in practice tends to lead to disrespect for the law". ${ }^{88}$ Several authors have concretised specific proposals on how to implement rules that allow the practice of euthanasia while safeguarding the rights and interests of everyone involved. ${ }^{89}$ Examples of statutory laws permitting the practice of active euthanasia or assisted suicide that have been implemented thus far, namely those in Belgium and in The Netherlands, are undoubtedly high-quality examples of how legal rules can reach a balanced compromise between the interests of all persons involved and the precautionary duties of public authorities.

The clear and dangerous difference that exists between the countries that assume a frontal and open policy concerning euthanasia-related practices and those that do not is that in the latter, these practices take place without any regulation or control. It seems that legal responses to the practice of euthanasia are part of a wider, complex social game, in which legal and medical terminology and language in general are manipulated and euphemisms are invented in order to accommodate bad moral consciences and avoid political unrest. Hypocrisy reigns. The ultimate goal of medicine should eventually no longer be perceived as prolonging life at any cost, but promoting well being and eliminating suffering. Although saving lives should remain the guiding principle, this principle can, and should, yield to compassion and respect for the patient's self-determination.

87. M. Otlowski, op. cit., pp. 456-457.

88. Ibidem.

89. For a set of possible reform alternatives, see M. Otlowski, op. cit., pp. 456-493; J. M. Freeman, "If euthanasia were licit", in McMillan, Richard C.; Spicker, Stuart F.; Engelhardt Jr., Tristram Hugo; "Euthanasia and the newborn: conflicts regarding saving lives", Dordrecht; D. Reidel Publishing Company, 1987, pp. 166-167; A. A. Morris; "Voluntary Euthanasia", Washington Law Review, 1970, pp. 239 ff; F.G. Miller, T.E. Quill, H. Brody et al., "Regulating physician-assisted death", in N. Engl. J. Med., 331, 1994, pp. 119-123. 